\title{
STRATEGIC SYNERGIES AND PERSPECTIVES OF THEIR EVALUATION IN THE PROCESS OF STRATEGIC ANALYSIS
}

\author{
Marek Blaszczyk \\ SGH Warsaw School of Economics, Warsaw, Poland \\ ORCID: 0000-0002-2740-684X; e-mail: marek.blaszczyk@sgh.waw.pl \\ (C) 2018 Marek Błaszczyk \\ This is an open access article distributed under the Creative Commons Attribution-NonCommercial-NoDerivs license \\ (http://creativecommons.org/licenses/by-nc-nd/3.0/) \\ DOI: $10.15611 / \mathrm{ms} .2018 .4 .02$ \\ JEL Classification: O43, O32, O33, D83
}

\begin{abstract}
Although the subject of synergy has been explored for a long time, there are many indications that it is still gaining in importance, in the field of economics. The phenomenon of synergy seems particularly important in the field of M\&A's, alliances and the development of new organizational forms of enterprises. Synergy effects are most often evaluated from the operational and very rarely in the strategic, structural perspectives. The aim of the article is to identify and systematize the most important perspectives for synergy effect evaluation in the process of strategic analysis. The identified perspectives will be the starting point of the further research on criteria selection for synergy effects evaluation and will be one of the components of a more complex framework of the process of resource analysis. The research was conceptual, based on a literature review in the fields of methodology of strategic analysis, strategic management and Resource-Based View (RBV) approach. The identification of the structural conditions for synergy effect evaluation, requires focusing on: the subjective scope of the synergy effect analysis, key areas of strategy content and context, with the important role of strategic resources.
\end{abstract}

Keywords: strategy, synergy, strategic analysis, resources, core competencies.

\section{Introduction}

The phenomenon of synergy is not new, both in the general sense and in relation to certain science disciplines on the basis of which it is identified and analyzed [Suszyński 1988; 1992]. The subject of synergy occupies a special place in economic sciences, and although this issue has been explored for a long time, there are many indications that it is still gaining in importance. Synergy plays an important role in business administration, including strategic management and enterprise value management. Due to the synergy's essence, it seems particularly important in the areas of mergers and acquisitions, and the cooperation and development of new organizational forms of enterprises - in particular those that are based on various forms of cooperation and the creation and development of relational resources.

What attracts particular attention is that synergy effects are an important subject of interest of business administration areas related to growth and devel- opment strategies (including the diversification of the business structure) and the methods of strategy implementation (mainly external growth). To the greatest extent, the synergy effects are taken into account, analyzed and evaluated in the literature and in the research concerning mergers and acquisitions, and to a much lesser extent the area of strategic alliances, cooperation, and the development of new organizational forms [cf. e.g., Scopus, Emerald Database, McKinsey Quarterly Search Engine, Harvard Business Review, Google Scholar, Google Search Engine]. This suggests that potential for gaining synergy effects is hypothetically comparable for various external growth strategies [Ernst, Halevy 2003], but in practice is most risky in M\&A transactions (the problem of the low efficiency of these strategies) [Sirower 1997, pp. 85, 123; Pierścionek 2011, p. 430; Zenger 2016 p. 2; Agrawal et al. 2017, p. 2]. In the M\&A area, the main research focuses on the operational motives, companies integration as well as on operational synergies (largely on cost 
synergy) [Gehner et al. 2010, p. 7; Ferrer et al. 2013, p. 4; Rudnicki 2017, p. 2].

In the literature and research on alliances, cooperation and development of new organizational forms, a lot of attention is paid to the benefits of implementing these strategies (goals and motives, premises and threats, positive and negative effects), but these benefits are not defined directly (expressis verbis) in terms of synergy effects, although in fact they often concern this issue [i.e. Romanowska 1997; Doz, Hamel 1998; Spekman et al. 2000; Cygler 2002]. Also, in the literature on enterprise resources (RBV), relatively little attention is paid to the subject of synergy, considering the importance of its issue. Methods of resource analysis and evaluation (i.e. [Porter 1985; Lisiński 2004; Gierszewska, Romanowska 2017; Grant 2016]) and methods and criteria for assessing the strategic value of resources, previously developed and disseminated in the literature of RBV, do not directly take into account the assessment of potential synergy effects [Hamel, Prahalad 1990; 1999; Barney 1991; Godziszewski 2001; Stankiewicz 2005]. Synergy effects are also most often assessed from two important but not crucial - for the strategic management process perspectives, i.e. from a general perspective (the overall impact of synergy effects on financial results and the value of the company) [Gehner et al. 2010], and from an operational perspective [Kaplan, Norton 2011]. Interestingly, the strategic assessment of synergy effects requires in-depth structural analyzes based on: 1) the determination of the most important perspectives for the identification and assessment of synergistic effects; 2) the identification of the most important potential sources and types of synergies, 3) defining strategic criteria for the assessment of synergistic effects, 4 ) evaluating (ex-ante) the potential synergistic effects and their further verification (expost).

The aim of the article is to identify and systematize the most important perspectives of synergy effects evaluation in the process of the strategic analysis of a company. The identified perspectives will be the starting point of the further research on criteria selection for the evaluation of synergy effects. These criteria can be identified in the most important fields of the strategic analysis process, especially in the field of a company competitiveness analysis. The assessment of potential synergistic effects will constitute one of the components of a more complex framework of the resource analysis process in the future research. Bearing in mind the goals of our further research, the author focuses particularly on the resource perspective (RBV perspective), which can be a relatively universal foundation in the analysis and assessment of synergistic effects. The main objective of the research (conceptual and empirical), for which the author identifies the most important perspectives for identifying and assessing synergy effects, is to develop and empirically verify the methods of analysis and evaluation of the resources' strategic value, including the strategic criteria of resource evaluation, that will take greater account of (in the subjective scope) potential possibilities of achieving synergy effects. The assessment of potential synergistic effects will be one of the components of the more complex framework for resource analysis process. The identified prospects for the analysis of synergy effects may also be more widely used for other analyses of the potential effects of resource strategies, cooperation strategies or mergers and acquisitions, including the assessment of the potential limitations, threats and negative effects of selected strategies.

\section{The essence of synergy effects and the basic conditions for their analysis and evaluation}

The term synergy is not a new concept in economic sciences, but it does not have a long history either. The PWE Small Economic Encyclopedia of 1974 does not define this term directly, but names the essence of synergistic factors as "factors that strengthen or intensify the action of other factors (one or many). Hence, they also have a co-operative character in inducing, creating and during the course of a given phenomenon (...) if there a process of intensifying the effect is present" [Mała... 1974]. C. Suszyński, one of the precursors of synergy effects research, presents a detailed analysis of the origin, interpretation and the first appearance of the term synergy in economic sciences [Suszyński 1988; 1992, pp. 11-17]. The author defines synergy in terms of the "intended effects", as a result of economic activity as the "noticeable, additional joint effect of actions taken to achieve previously defined goals (...) and the size of achieved effects higher than the previously adopted one (...) is a special feature of this phenomenon" [Suszyński 1992, pp. 17-18]. The author points out, inter alia, that the study of the economic phenomenon of synergy requires considering the possibility of evaluating effects in measurable terms, as well as necessitates the analysis of these effects' sources, hence conditions, sources and effects define the essence of this phenomenon more closely [Suszyński 1992, p. 15].

As mentioned before, synergy is most often defined from the perspective of the selection and 
evaluation of merger and acquisition strategies, although it should be noted that synergy effects do not only accompany merger processes and other forms of external development, but may relate to combining different business areas and functions in one enterprise, including, among others, diversification strategy effects [Ansoff 1965; Salter, Weinhold 1979]. However we can see a general consensus among the various sources that synergy effects are one of the basic objectives of the acquisition strategies [Steiner 1975; Salter, Weinhold 1979; Sirower 1997; Mesjasz, Szarucki 2017] and, among others, from this perspective, the essence of this phenomenon can be more clearly defined. The synergy of merging economic entities means "the achievement of added value thanks to combining two or more enterprises, while reaching this value would be impossible without performing this operation" [Strategor 1995, p. 210]. Interestingly, the core of the synergy effect is defined similarly in various sources e.g. "we can talk about synergy effects when the economic value created by cooperating business units exceeds the value that these business units can create by acting independently" [Ireland et al. 2008, p. 164]. M. Lewandowski states that "the concept of synergy refers to a situation in which a combination of components gives more than their simple sum" [Lewandowski 2009, p. 34]. Such an understanding of the synergy effects also distinguishes the very symbiosis effect, e.g. bilateral benefits, that exists between various institutions and areas of socioeconomic life, from the profits (additional economic value) that should be generated as a result of cooperation or merging various entities, or more broadly, areas of company's activities. The concept of synergy often seems to be overused when it indicates just the symbiosis effect.

It is interesting that synergy effects are often presented symbolically by the formula $1+1=3$ (or $2+2=5$ ) (see e.g. [Strategor 1995, p. 210; Lewandowski 2009, p. 34]). It should be noted that due to the symbolic meaning, it is not precise because it is not possible to accurately estimate the effects of synergy, both ex-ante and ex-post. In the ex-ante evaluation, it is not only difficult to identify the possible potential effects, but it is also difficult to assess whether the achieved effects will be stronger or weaker than previously intended. In the ex-post evaluation, a significant barrier is not only the variability of the conditions in which the enterprise operates, but the high complexity of the cause and effect relationships, the uneven distribution of effects and the changing value of the company in time (in which time period should these effects be evaluated?). Also due to the objective difficulty of estimating synergy effects, it seems more justified to use the formula $V(A B)$ $>\mathrm{V}(\mathrm{A})+\mathrm{V}(\mathrm{B})$, where $\mathrm{V}(\mathrm{AB})$ is the value of the combined companies, and $\mathrm{V}(\mathrm{A})$ and $\mathrm{V}(\mathrm{B})$ are: value of company A and value of company $\mathrm{B}$, respectively - operating independently (cf. [Damodaran 2006, p. 542]), because such a formula does not predetermine the strength of potential effects, but only indicates the condition defining the spirit of synergy. An assessment of the synergistic benefits in M\&A transactions also requires the inclusion of additional economic unit acquisition costs, defined in terms of transaction costs and a bonus for obtaining control [Gaughan 2007 , p. 124]. As theory and practice shows, synergy effects are not always present and are often lower than previously expected (e.g. [Sirower 1997; Bruner 2002, p. 63, Korpus 2014, p. 112]), which also forces us to reflect on the necessity of conducting strategic analyzes dedicated to this issue. Therefore the main causes of failures of mergers and acquisitions are most often defined in terms of internal conditions such as cultural and organizational conditions, enterprise integration processes, human resources management, but the strategic assessment of synergy effects including failures, requires simultaneous orientation to the internal and external conditions of processes.

The aforementioned conditions defining the essence of synergy effects that: 1) exclude outcomes obtainable outside the merger process of enterprises, or more broadly markets, sectors and resources, and 2) require considering in the economic calculation both the acquisition costs of the unit and the achievable effects of the merger processes, they also force one to reflect on the need to analyze and evaluate alternative options to obtain synergy effects and to take into account the costs of alternative solutions. Comparative analyzes concerning the substitutability of potential synergy sources and effects could also take more into account, in addition to the costs of implementing the strategy (in alternative solutions), such evaluation criteria as the time required to implement the strategy, level of risk and strategy flexibility.

\section{Prospects for identification, analysis and evaluation of strategic synergy effects}

Synergistic effects are often assessed generally and quantitatively, as the total sum of benefits resulting from the merger (including increased market shares, improvement of financial results, increase in company value), while relatively little attention is paid to the assessment of synergy effects in terms of qualitative and structural analyzes (areas and types of synergies, synergy sources and effects). 
Although it is difficult to precisely define the differences between the "strategic" and "operational" dimension, due to the complex nature of the strategy which has both a strategic and operational dimension, and the criteria are ambiguous, the author supports the view that the strategic dimension of synergy effects can be defined on the basis of the strategic management's key issues and main areas of the strategic analysis process that: a) define the content of the strategy and take into account the key issues of strategic management (cf. [Thompson, Strickland 1999, p. 11]); b) take into consideration the content of the strategy and the specificity of the most important issues that are characteristic for particular levels of strategic management (network, corporation and competitive level) [Pierścionek 2011, pp. 17-20]; c) consider the most important areas of the strategy context (macro and micro environment, including: markets, sectors, and resources) in the strategic analysis process [Porter 1980; Lisiński 2004, p. 38; Grant 2016, pp. 24, 34, 113; Gierszewska, Romanowska 2009; 2017, pp. 22-25]. What is more, the identification of the most important perspectives for the analysis and assessment of synergistic effects in the strategic and structural dimension also requires a broader consideration of the complex subject range, as the analysis of synergy effects may be conducted for different types of enterprises.

Therefore identification of research perspectives thus requires focusing on the following points: 1) the subjective scope of the synergy areas and effects analysis; 2) the key areas and strategic management issues defining the strategy content; and 3) the key areas for assessing the conditions of strategy implementation (strategy context). The aim of the next part of the article is to present the most important perspectives for the analysis and assessment of synergy effects, without a detailed indication and systematization of the sources and criteria for the evaluation of synergistic effects thus constituting a further problem and research goals).

It is important to point out that the subjective scope of the analysis, which sets the general analysis framework, is the starting point in the analysis of the synergistic effects. Hence, synergy effects can occur both in the enterprise itself and outside the enterprise. Due to the relatively large potential benefits of synergy effects, the merging or cooperating enterprises are the main subject of analysis. However, synergy effects that can be directly used by enterprises may occur outside the enterprise and at the border of the enterprise and other entities or institutions of social life (e.g. cooperation of research and scientific institutions, government institutions, the banking system, etc.).
Furthermore, synergy effects can be identified on the basis of a specific strategy content and context.

The term of synergy area is not precise because it does not explain whether it is a space in which synergy effects arise or a space in which these effects can be observed and identified. On the subject of synergy areas, we can therefore consider both the sources and effects accompanying this phenomenon. The demarcation of synergy areas according to the sources and effects will not always be obvious and unambiguous. Selected effects can be identified simultaneously from different perspectives or they can be created by combining resources, markets or with the participation of many entities, not only economic. For example, a synergy may occur between the company and the market in the process of co-creating value for the customer (cf. for example [Prahalad, Ramaswamy 2004; Bartkowiak 2017]). If the effects of synergy can be triggered for various reasons and can occur in different places, then it means that it may be legitimate to talk about different types of synergy.

Focusing on the synergies that can be generated or used by enterprises, in the first place these effects can be assessed from the perspective of a single economic entity as well as from the perspective of the merging or cooperating enterprises. When regarding single enterprises, we can consider both the internal perspective (the company and its resources) and the external one (the sector and market environment of the enterprise and its macroeconomic environment ). The category of individual enterprises is not uniform because it can mean both a small specialized enterprise and large corporations and their individual business units with a diversified organizational structure that operate simultaneously on many markets and in many sectors that create, acquire and use resources in many ways. The perspective of many entities is first of all an assessment of the synergy effects that may occur between merging or cooperating enterprises and other entities of social and economic life. Because the basic forms of cooperation between companies with various stakeholder groups (suppliers, recipients, owners, shareholders, managers, employees, research and development institutions, state government and local government institutions, other stakeholder groups) occur in any organizational form, regardless of the type of strategies implemented, this includes all forms of enterprises' acquisition, and more advanced or formalized forms of cooperation, including strategic alliances and network enterprises. Advanced forms of cooperation can be defined on the basis of such criteria as the significance of cooperation (the significance of common strategic objectives), the scope of cooperation (in the market and sector 
dimensions), the scope of engagement or the joint use of resources (merging or cooperating enterprises), and the importance of resources (involved or created). Particularly noteworthy are vertical links in which various economic entities take a direct part in the process of creating added value.

Synergy effects that can be generated or used by individual enterprises as well as cooperating or merging enterprises can be identified from three main perspectives: 1) resources, 2) markets, and 3) sectors [Błaszczyk 2016, pp. 78, 85]. The resource perspective presents extensive opportunities to identify synergy effects regardless of the scale and scope of the company's operation, because the basic synergy effects may occur as a result of combining both knowledge and skills (substantive and personality-related) of individual employees or these effects may result from combining different types of resources. The strategic perspective focuses attention on the resources understood in terms of the most important processes and functions that the company implements. The market and sector perspective allow to identify synergy effects, although the possibilities of generating them seem to be more dependent on the scale and scope of the company's operations.

According to the literature analysis, the greatest opportunities to achieve synergy effects are open to companies that implement product-market diversification, in particular market-related diversification. To achieve market synergy it is not necessary to implement an external growth strategy, as the strategy and structure of markets alone may be a source of this synergy. The opportunities of achieving market synergy effects for enterprises with a high level of specialization seem to be much more limited (in the case of very narrow market specialization not much is possible). However these effects may also occur when a company is present in various segments of the market with a high degree of relatedness - complementary nature of markets or strong impact of results achieved in one segment on the results obtained in other market segments). For example, the very strong position of the company in prestigious, innovative, and technologically advanced, market segments may have an impact on the company's results obtained in other, e.g. lower, mass market segments. The concept of market synergy most often concerns enterprises pursuing a strategy of related diversification with a high level of affinity of markets, however, we can identify similar mechanisms from the perspective of specialized enterprises that operate in many segments of one market. Companies that offer a wide portfolio of products and services, even with a small diversity of markets, can achieve the effects of product-market synergy resulting from the complementary nature of the products and services offered, including crossselling in marketing strategies. Market synergies can also be evaluated more broadly on the basis of benefits, defined in terms of value to customer, if the company can deliver more value.

There is no doubt that the effects of market synergy may coincide, but they are not identical to the effects achieved in the sectoral dimension. While market synergy means the benefits associated with the functioning of a given enterprise in many related markets or segments, the synergy of sectors means the additional competitive effects related to a change in the structure of competitive forces, position in the sector and strategic group map, or a change in the value chain such as an improvement of the company's position in the horizontal and/or vertical links in the sector. The synergy effects identified in the sector itself may result from high the relatedness of business sectors and a better use of resources e.g. the common supply sources or distribution channels, technology transfer opportunities, better effects of resources commercialization, extended economies of scale, increasing bargaining power and negotiation, decreasing costs, etc.. The synergy effects observed from a sector perspective may have their sources both on the market and on the resources side. Individual enterprises can achieve sector synergy effects when the implemented or intended strategy allows more efficient creation, acquisition or the use of resources in these sectors, while merging or cooperating enterprises may additionally achieve the effects of resources integration and coordination (similar or complementary).

It has been found that the effects of market synergy can be assessed on the basis of the scope and growth of the market potential of the enterprise and on the basis of the benefits perceived by the final recipients (synergy effects that generate direct sources of value to the customer), while the assessment of sectoral synergy effects requires the analysis and assessment of how the changing resources of enterprises (own and external, current and potential, sectoral and extraor supra-sectoral), and the changing scope of activity in the dimension of markets and sectors affects the position of the enterprise in the system of horizontal and vertical links in the sector.

By focusing on the resources themselves, the synergy effects can be identified from several perspectives. The dominant, but not the only, perspective of resource analysis seems to be the sectoral value chain. Synergistic effects can be obtained here both from the perspective of individual links in the chain, e.g. the effects of combining the 
potential of enterprises with similar resources and skills in the case of horizontal, i.e. acquisitions, alliances and cooperation, which may also occur through combining complementary resources in both horizontal and vertical relations. Complementarity of resources can occur in horizontal relationships when similar enterprises from the same link of the economic path have different resources and complement each other. Synergistic effects can be achieved primarily due to the fact that by combining complementary resources, a company can better use its own or partner's resources, and better develop previously controlled or new resources. Combining similar resources, for example a geographic range of distribution channels, within a given link in the value chain will in turn favour the achievement of scale, scope and network effects.

Although, in the assessment of potential synergy effects, special attention is focused on complementary resources (the effects of their combination and effective use), also resources with similar characteristics and mutually substitutable resources may generate synergy effects by: a) combining potential (e.g. combining financial potential and different sources of financing operations in consolidation processes), and $b$ ) by reducing ineffective resources (operational synergies).

A crucial role in synergy identification can also be played by the perspective of core competences [Hamel, Prahalad 1990; 1999]. This perspective differs from the one earlier indicated, in that it may be of a cross-sectoral nature and may signify processes of diversification, merger (convergence) and the full use of resources in many sectors. Complementarity of resources is understood differently here than within a particular sectoral value chain, because it may concern the possibility of combining different types of resources that will be a source of innovation, creating new sources of value, new products and new sectors of activity. Combining core competences (resources of individual enterprises or many enterprises) is also a source of market-related or technologicallyrelated diversification, when the existing and the new resources are simultaneously used. Core competences determine new strategic opportunities (new sources of value to customer, new markets and sectors, new sources of growth) and synergy benefits can also be evaluated here in more detail.

Referring closer to the core competence concept, synergistic effects can be evaluated from the perspective of the "architecture" of core competences and independently from the "resources as leverage" concept [Hamel, Prahalad 1990; 1999, p. 132; Koruna 2004, pp. 505-516]. The architecture of core competences, characterizes the basic relationships between resources, core-products and end-products, which together form a specific structure. Synergy effects may result either from the transfer or integration of core competences, as well as the transfer and integration of core products in new ways, to create new end products and new sources of value to customer. Hence, the architecture of core competences not only determines the innovation potential but also has a fundamental impact on the company's flexibility in the product-market and resources dimension of strategic diversification. Considering the concept of leverage resources in the analysis of synergy effects means that we can also assess these effects from the perspective of the process of creating, acquiring and using strategic resources in an efficient way (creation, acquisition, accumulation, transferring, integration) using various development methods and organizational forms.

Paying attention to the subjective scope of the synergy effects analysis from the perspective of the resources themselves in the area of the most important links in the value chain and core competencies, these effects can be evaluated depending on the purpose of the analysis and the nature of the analyzed strategic problem from the following angles: 1) own and external resources (in the analysis of the cooperation and merger processes); 2) current and new resources (newly created, acquired or jointly created); and 3) sectoral resources (related to the sectoral value chain) and non-sectoral resources (resources created or previously commercialized in other sectors that can be a source of diversification).

An important aspect of identifying, analyzing and assessing synergy effects is to consider the most important elements of the strategy content. Competition strategies can be evaluated in the process of strategic analysis from the market perspective (value for the customer and key success factors) and the sector (sectoral conditions and strategy instruments as the company's response to the given conditions), therefore special attention is paid to the growth and development strategies themselves. Enterprises can implement different strategies and achieve their goals using various organizational methods and forms. Development strategies are primarily a kind of expansion (sectoral and geographical), direction of expansion (horizontal, vertical and diversified) and methods and forms of strategy implementation (internal and external methods). A relatively universal and key prospect for the assessment of synergy effects seems to be the issue of business development directions because they allow the use of different mechanisms and types of synergy. Subsequently, 


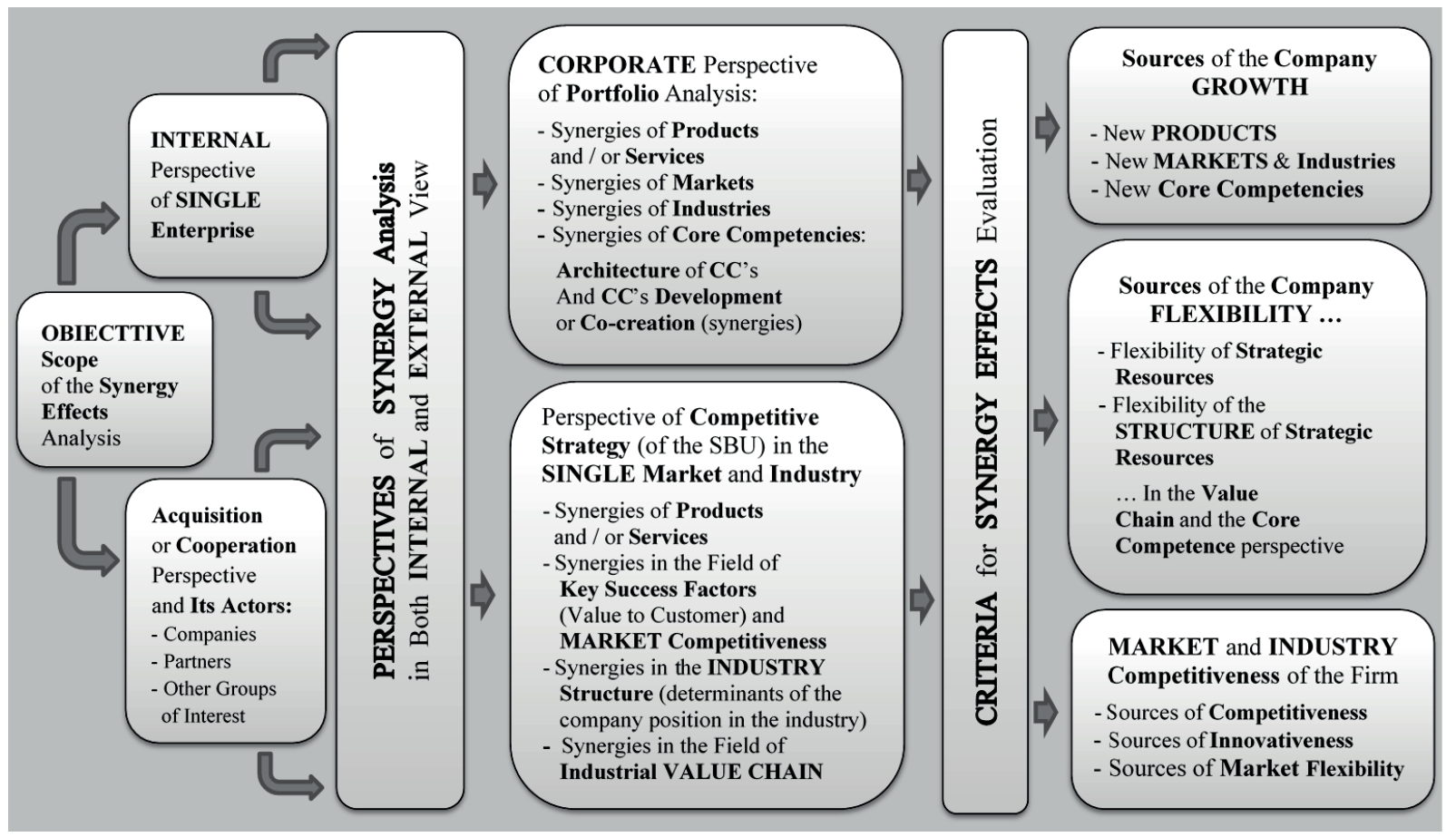

Fig. 1. Objective scope and perspectives of the evaluation of synergy effects

Source: based on own research.

individual development directions can be implemented through various methods of growth and development and different organizational forms, which draws attention to alternative forms of development.

The most remarkable directions of the enterprises' development that can determine different synergy effects include primarily: 1) horizontal sectoral expansion and geographical (expanding the scope of activity or the scope of specialization through cooperation strategies, alliances and horizontal connections; 2) vertical expansion within the sectoral value chain (expanding or combining different areas of resources specialization through alliances, cooperation and vertical connections), which does not lead to diversification of the product-market structure, 3 ) related (in terms of a market or technology) and unrelated diversification (product-market), 4) vertical diversification (expansion within the sectoral value chain that leads to the diversification of the productmarket structure), 5) diversification of resources (core competencies) - expansion beyond the sectoral value chain that can lead to all types of diversification (product-market). Although each type and method of strategy implementation may generate other specific synergy effects, we can also talk about similarities in synergy mechanisms - (within particular development directions.

It has been found that horizontal expansion, associated with the specialization and expansion of the activity scope, which does not lead to sectoral diversification, allows first of all to achieve synergies based on combining or the better use of resources, extending the effects of scale, scope and diversity or networks. Horizontal expansion also gives, in the case of the strategy of combining the potential of enterprises characterized with similar resources, additional possibilities of reducing inefficient organizational structures e.g. duplicated departments and functions and other resources, including material ones. Specific synergistic effects can be identified and evaluated from a chosen perspective such as a particular type of strategy, scope, areas and analysis perspectives - resources, market, sector. Vertical expansion, which does not lead to diversification, but integration and quasi-vertical integration or outsourcing and structures reduction, is primarily manifested in the effects of combining complementary resources and the possibility of the better coordination of various links in the sectoral value chain, the socalled cross-functional optimization [Porter 1985, pp. 11-15, Strategor 1995, p. 66]. Synergistic effects may also result from the very fact of acquiring or combining strategic resources characterized with high potential e.g. one company has this potential but another company can better commercialize it, which also means complementarity of resources owned by merging or cooperating enterprises. The potential effects of the diversification strategy (horizontal 
and vertical, related and unrelated, and market or technology-related), including, among others, the possibilities of achieving different types of synergy effects, are the subject of a broader interest which is reflected in the literature on corporate strategies. Synergy effects not only accompany but define the essence of related diversification [Ansoff 1965; Wrigley 1970]. The related diversification enables a better use of resources and may be a source of market or technological synergies, whereas non-related diversification enables achieving financial synergy effects (see [Pierścionek 2011, p. 331]).

Taken together, the structural evaluation of the potential sources and effects of synergy requires confronting general sources of synergy (the effects of scale, scope, differentiation and network, and the effects of combining similar, substitutive and complementary resources) with the specificity of particular synergy areas. Synergistic effects should also be assessed globally based on operation results, taking into account their impact on the company's value increase. The assessment of operational effects as well as the methods of business valuation constitute an important research problem here, which is strongly reflected in the literature on company value as well as mergers and acquisitions.

\section{Conclusions}

Although synergistic effects may be a source of strategic benefits, literature and empirical studies indicate that they are much more often evaluated from an operational or general perspective (too general to allow for a deeper structural analysis ). Hence, the structural analysis of the strategic synergy effects requires: 1) the identification of potential prospects for analysis and an evaluation of these effects; 2) the identification of synergistic areas, according to sources and to effects; 3) defining strategic criteria for the assessment of synergistic effects and benefits, 4) evaluating potential synergy effects (ex-ante) and their further verification (ex-post) in the selected areas of strategic analysis.

The areas of synergy and the main prospects for their evaluation require attention to: 1) the subjective scope of the analysis process (taking into account not the perspective of merging and cooperating companies or other stakeholders but considering individual enterprises, areas of their operation and same resources as well as possible prospects for their analysis and evaluation ) ;2) the most important areas of the strategy context (mainly the markets, sectors and strategic resources); 3 ) the most important elements of the strategy content (primarily the possible expansion directions and methods of their implementation. The resources synergy effects may be assessed from the perspective of the sectoral value chain as well as from the perspective of core competencies (sectoral and over-sectoral resources, current and potential, own and external resources).

Narrowing the scope, the general sources of synergy effects such as the effects of scale, scope, diversity and networks, as well as the effects of combining similar, substitutive and complementary resources should be confronted with the specificity of the most important areas of context and content of the strategy (including, inter alia, the directions of enterprise expansion and their specificity in the process of generating synergy effects). Further evaluation of the synergy effects requires deeper clarification of the criteria for the assessment of the strategic benefits in the proposed areas (perspectives) of the analysis of these effects.

\section{Bibliography}

Agrawal A., Varma R., West A., 2017, Making M\&A deal synergies count, McKinsey on Finance, no. 64, McKinsey\&Company.

Ansoff H.I., 1965, Corporate Strategy, McGraw-Hill Book Co., New York.

Barney J., 1991, Firm resources and sustained competitive advantage, Journal of Management, vol. 12, pp. 99-120.

Bartkowiak P., 2017, Znaczenie składowych procesu wspótkreowania wartości dla klienta $w$ perspektywie wyborów strategicznych, Handel Wewnętrzny, maj-czerwiec 2017, no. 3 (368), vol. 1, Instytut Badań Rynku, Konsumpcji i Koniunktur.

Błaszczyk M., 2016, Strategiczne pola konkurowania a strategie konkurencji, [in:] Strategiczne pola konkurowania, (ed.) M. Poniatowska-Jaksch, Oficyna Wydawnicza SGH, Warszawa.

Bruner R.F., 2002, Does M\&A Pay? A survey of evidence for the decision-maker, Journal of Applied Finance, Spring-Summer.

Cygler J., 2002, Alianse strategiczne, Difin, Warszawa.

Damodaran A., 2006, Damodaran on Valuation: Security Analysis for Investment and Corporate Finance, John Wiley\&Sons, Hoboken.

Doz Y.L., Hamel G., 1998, Alliance Advantage. The Art of Creating Value through Partnering, Harvard Business School Press, Boston.

Ernst D., Halevy T., 2004, Not by M\&A alone, The McKinsey Quarterly, no. 1

Ferrer C., Uhlaner R., West A., 2013, M\&A as Competitive Advantage, McKinsey \& Company, August.

Gaughan P.A., 2007, Mergers, Acquisitions and Corporate Restructurings, John Wiley\&Sons, Hoboken.

Gehner L., Holthaus J., Nieden F., 2010, International M\&A Study 2010. Success of $M \& A$ strategies as pursued by banks, Frankfurt (source: zeb/rolfes.schierenbeck.associates, printed report).

Gierszewska G., Romanowska M., 2009, Analiza strategiczna przedsiębiorstwa, PWE, Warszawa.

Gierszewska G., Romanowska M., 2017, Analiza strategiczna przedsiębiorstwa, PWE, Warszawa. 
Godziszewski B., 2001, Zasobowe uwarunkowania strategii przedsiębiorstwa, Wydawnictwo Naukowe UMK, Toruń.

Grant R.M., 2016, Wspótczesna analiza strategii, Wydawnictwo Nieoczywiste.

Hamel G., Prahalad C.K., 1990, The core competencies of the corporation, Harvard Business Review, May-June, vol. 68, no. 3, pp. 79-91.

Hamel G., Prahalad C.K., 1999, Przewaga konkurencyjna jutra. Strategie przejmowania kontroli nad branża i tworzenia rynków przyszłości, Business Press, Warszawa.

Ireland R.D., Hoskisson R.E., Hitt M.A. 2008, The Management of Strategy. Concepts, $10^{\text {th }}$ edition, South-Western CENGAGE Learning.

Kaplan R.S., Norton D.P., 2011, Dopasowanie w biznesie. Jak stosować strategiczna kartę wyników, Gdańskie Wydawnictwo Psychologiczne.

Korpus J., 2014, Przebieg procesów fuzji i przejęć. Determinanty sukcesu przebiegu transakcji, [in:] Fuzje i przejęcia, J. Korpus (ed.), Wydawnictwa Profesjonalne PWN, Warszawa.

Koruna S., 2004, Leveraging knowledge assets: combinative capabilities - theory and practice, R\&D Management, vol. 34, no. 5 , pp. 505-516.

Lewandowski M., 2009, Motywy nabywcy i sprzedawcy, [in:] Fuzje i przejęcia, Frąckowiak W. (ed.), Polskie Wydawnictwo Ekonomiczne, Warszawa.

Lisiński M., 2004, Metody planowania strategicznego, PWE, Warszawa.

Mała encyklopedia ekonomiczna, 1974, Państwowe Wydawnictwo Ekonomiczne, Warszawa.

Mesjasz Cz., Szarucki M., 2017, Synergia i przewidywanie w strategii fuzji i przejęć, Studia Oeconomica Posnaniensia, vol. 5, no. 9, Wydawnictwo Uniwersytetu Ekonomicznego w Poznaniu, Poznań.

Pierścionek Z., 2011, Zarzadzanie strategiczne w przedsiębiorstwie, Wydawnictwo Naukowe PWN, Warszawa.
Porter M.E., 1980, Competitive Strategy. Techniques for Analyzing Industries and Competitors, The Free Press, New York.

Porter M.E., 1985, Competitive Advantage, The Free Press, New York.

Prahalad C.K., Ramaswamy V., 2004, The Future of Competition, Harvard Business School Press, Boston.

Romanowska M., 1997, Alianse strategiczne przedsiębiorstw, PWE, Warszawa.

Rudnicki J., Thorpe R., West A., 2017, The Artful Synergist, or How to Get More Value from Mergers and Acquisitions, Corporate Finance, February, McKinsey\&Company.

Salter M.S., Weinhold W.A., 1979, Diversification through Acquisition, The Free Press, New York.

Sirower M.L., 1997, The Synergy Trap. How Companies Lose the Acquisition Game, The Free Press.

Spekman R.E., Isabella L.A., MacAvoy Th.C., 2000, Alliance Competence. Maximizing the Value of Your Partnerships, John Wiley \& Sons, Inc., New York.

Stankiewcz M.J., 2005, Konkurencyjność przedsiębiorstwa. Budowanie konkurencyjności przedsiębiorstwa $w$ warunkach globalizacji, TNOIK „Dom Organizatora”, Torun.

Strategor, 1995, Zarzadzanie firma. Strategie, Struktury, Decyzje, Tożsamość, Państwowe Wydawnictwo Ekonomiczne, Warszawa.

Suszyński C., 1988, Synergia $w$ działalności przedsiębiorstw, Szkoła Główna Planowania i Statystyki, Warszawa.

Suszyński C., 1992, Synergia w działalności rynkowej przedsiębiorstw, Monografie i Opracowania, nr 355, Szkoła Główna Handlowa, Warszawa, pp. 9-31.

Thompson A.A., Strickland A.J., 1999, Strategic Management. Concepts and Cases, $11^{\text {th }}$ edition, Irwin McGraw-Hill.

Wrigley L., 1970, Divisional Autonomy and Diversification, Harvard University, Boston.

Zenger T., 2016, Do M\&A deals ever really create synergies?, Harvard Business Review, July 06, Harvard Business School Publishing Corporation.

\section{STRATEGICZNE SYNERGIE I PERSPEKTYWY ICH OCENY W PROCESIE ANALIZY STRATEGICZNEJ}

Streszczenie: Mimo iż tematyka efektów synergii jest eksplorowana od dłuższego czasu, wiele wskazuje, iż zagadnienie to wciąż zyskuje na znaczeniu. Zjawisko synergii jest szczególnie ważne w obszarze problematyki: fuzji i przejęć, aliansów strategicznych oraz rozwoju nowych form organizacyjnych przedsiębiorstw. Efekty synergii najczęściej oceniane są z perspektywy operacyjnej, znacznie rzadziej z perspektywy strategicznej i strukturalnej. Celem artykułu jest zidentyfikowanie i usystematyzowanie najważniejszych perspektyw oceny efektów synergii w procesie analizy strategicznej. Zidentyfikowane perspektywy stanowią punkt wyjścia do opracowania kryteriów oceny efektów synergicznych, jak również stanowią jeden z komponentów nowej propozycji szerszego schematu analizy zasobów i oceny ich wartości strategicznej. Badanie ma charakter koncepcyjny i bazuje na analizie literatury dotyczącej metodyki analiz strategicznych i zarządzania strategicznego, ze szczególnym uwzględnieniem dotychczasowego dorobku nurtu RBV.

Słowa kluczowe: strategia, synergia, analiza strategiczna, zasoby, kluczowe kompetencje. 